\title{
THE INTER-RELATIONSHIP OF VIRUSES AND BACTERIA IN INFECTIVE DISEASES
}

\author{
By D. Geraint James, M.D.(Cantab.), M.R.C.P.
}

The newer antibiotics-aureomycin, terramycin and chloramphenicol-are effective against a wide range of bacteria and all known rickettsiae, but are only of value against a small group of viruses. These viruses are the large structurally complex ones, measuring about 250 to 300 millimicrons in diameter and approximating to the size and to the other features of rickettsiae. These antibioticsensitive large viruses consist of the psittacosislymphogranuloma venereum group, the closelyrelated viruses of trachoma and inclusion conjunctivitis, and the agent, presumably viral, which causes cold haemagglutinin-positive primary atypical pneumonia. There is no good evidence that any other viruses are affected by these newer antibiotics, although numerous claims have been made of their efficacy in such virus diseases as influenza, herpes simplex, herpes zoster and chickenpox. The amelioration of symptoms is presumably due to control of secondary bacterial infection. In this manner, of course, the antibiotic favourably influences the course of the disease. However, the improvement in the patient's condition is due to a bacteriostatic, rather than any virucidal action, of the antibiotic.

The cold sore of the lip due to the herpes simplex virus runs an unmodified course when the newer antibiotics effectively terminate a concomitant bacterial pneumonia. When the virologist undertakes to isolate the influenza virus from sputum, various antibiotics can be added to the sputum to control the bacteria present. In no way does this hinder successful influenza virus isolation.

In view of the modifying influence of antibiotics on infectious disease processes, it is therefore pertinent to try to assess the relative roles of both bacteria and viruses. Frequently there is a close inter-relationship, or there may even be mutual interdependence between viruses and bacteria in the production of the natural disease.

\section{Veterinary Diseases}

There are many such instances, especially in the field of veterinary medicine. The virus of canine distemper paves the way for brucella bronchiseptica and salmonellae, which play an important role in this disease in dogs. The role of salmonellae in conjunction with a virus is well recognized in causing hog cholera, an acute contagious disease of swine. Contagious pleuro-pneumonia in horses is considered to be due to a virus, but the main pulmonary damage is caused by a streptococcus (Hagan and Bruner, 195I).

However, the best example is that of swine influenza, in which a virus and the haemophilus influenzae suis are both essential aetiological participants of the full-blown disease. The unfolding of this fascinating story (Shope, 1936) is a tribute to Shope's pioneer work since 1928. Experimental transmission of the swine influenza virus alone produces a mild 'filtrate disease' in which the lungs show heavy peribronchial cuffing with round cells and the alveolar walls are thickened and infiltrated by round cells. Leucocytes are conspicuously absent from the bronchi and affected alveoli. On the other hand, intranasal inoculation of mixtures of virus and haemophilus influenzae suis cause the prostrating respiratory disease, swine influenza, A purplish-red consolidation of the lungs is seen, with intense oedema, interstitial pneumonia and leucocytic infiltration of bronchi and alveoli.

When the human influenza virus is inoculated intranasally in pigs it causes a disease clinically and pathologically indistinguishable from the mild filtrate disease caused by the swine influenza virus. Furthermore, mixtures of human influenza virus and haemophilus influenzae suis cause a disease similar to swine influenza, although milder.

\section{Influénza}

The role of the haemophilus influenzae in human influenza was considered all-important at one time, but the discovery of the influenza virus forced it into the background. A combination of both virus and bacterium may influence the 
severity and course of human influenza. It is well recognized that pneumococci, streptococci and staphylococci determine the severity of influenzal pneumonia: The lung changes in influenza were described by Scadding in 1937, and the views he expressed still remain logical and accurate. Clinical investigation of influenzal pneumonia in the succeeding I 5 years has only served to confirm the conclusions based upon the influenza epidemic studied at Hammersmith Hospital in 1936-37. Scadding considers that the influenza virus destroys the protective mechanism of the respiratory tract, including the parenchyma of the lung, in a similar manner to poison gas, and so paves the way for bacterial invasion. The varying clinical pictures seen in influenzal pneumonia depend upon the extent and virulence of both virus and bacterial infection.

Infection by both influenza virus and staphylococcus aureus may result in a fulminating pneumonia in which the patient often dies within 24 hours of the onset of symptoms. Autopsy reveals a haemorrhagic tracheo-bronchopneumonia. The severity of this particular type of pneumonia, often unhalted by the newer antibiotics, would suggest an exalted virulence due to the synergistic action of virus and staphylococcus, possibly because of spreading by the hyaluronidase produced by the latter.

Experiments have been undertaken to observe the effects of influenza virus and haemolytic streptococci inoculated into monkeys (Wilson, Saslaw, Doan, Woolpert and Schwab, 1947). In contrast to the relative resistance of healthy: monkeys to either agent inoculated separately, serious infection occurred in five of eleven monkeys inoculated with haemolytic streptococci within' three weeks of influenza virus instillation. In the course of these experiments, five monkeys developed acute nephritis following varying combinations of virus and streptococci. It is difficult to assess the relative roles of each of these agents. Since nephritis only occurred in those animals which had received influenza virus at some time, the virus seems to have increased their susceptibility to subsequent bacterial infection.

\section{Common Cold}

Bacterial infection accompanies the virus of the common cold and is largely responsible for such complications as sinusitis, otitis media, and pneumonia. Much work on the bacteria associated with the uncomplicated common cold has been hampered by our ignorance of the normal nasopharyngeal bacterial flora and by lack of satisfactory methods of isolating and cultivating the common cold virus. The virus has been successfully transmitted to chimpanzees (Dochez, Mills and Kneeland, 1932). In both experimentally气 transmitted and naturally-occurring colds in these animals, they found a variation in the bacteria flora of the nasopharynx. Apart from an increasein the numbers and area of distribution of the: pneumococcus, haemolytic streptococcus, and haemophilus influenzae, there was also a transe formation in the haemophilus influenzae from the serologically non-type specific $\mathbf{R}$ form to the sero logically specific $\mathrm{S}$ form. During periods of health there was a reversion to the $R$ form.

Virus bacterial interdependence may be a factor in the disparity between spread of the natural and artificially-acquired common cold.

\section{Virus Pneumonia}

Virus-bacterial synergism may operate in the type of primary atypical pneumonia which associated with raised cold haemagglutinins. This acute respiratory tract infection is presumed to bee due to a virus, although such an agent has not ye been isolated and identified. Horsfall and his $c 0$ workers at the Hospital of the Rockefeller In stitute, New York, isolated the streptococcus M.G. (or 344) from the lungs of two fatal cases of primarq atypical pneumonia (Thomas, Mirick, Curnen,Ziegler and Horsfall, 1943). They showed that convalescent phase sera from patients with this condition agglutinated the organism, whereas acute phase sera failed, as did control sera fropis other acute respiratory tract infections and normal persons. This phenomenon is the basis of a tes used in conjunction with the cold haemagglutinin test for delineating a certain group of presumabl viral pneumonias.

This non-haemolytic streptococcus produceş small fluorescent colonies when grown on 5 peg cent. sucrose agar. It is immunologically related to streptococcus salivarius. It possesses a capsule which contains a poly-saccharide antigen respon:sible for its type specific serological reaction (Mirick, Thomas, Curnen and Horsfall, 1944).

The role of this bacterium, if any, in virus pneumonia is unknown. It is sensitive to penit cillin, whereas the disease itself is unaffected by this antibiotic. Thus it can be inferred that the streptococcus M.G., alone, contributes little to the: severity of the symptoms, although it may play part in combination with the virus. It may onlio bear some antigenic similarity to the causal agent of the disease, the latter providing the stimulus for the immunological response which is observed The streptococcus M.G. agglutination test, as used diagnostically in virus pneumonia, resembles the Weil-Felix reaction in that both depend upon the non-specific agglutination of a bacterium by the patient's serum.

The Commission on Acute Respiratory Diseaseo 
(1946) conducted extensive human transmission experiments on volunteers in an effort to isolate a virus from the throat-washings of patients with virus pneumonia. These experiments did not indicate any significant change in the bacterial flora of those volunteers developing the experimental disease, nor did they develop rising titres of streptococcus M.G. agglutinins. However, it was interesting to find striking differences in the incubation periods of the disease in those affected by unfiltered and by filtered throat washings. The group of volunteers inoculated with unfiltered material became ill in one week, whereas those receiving the filtered material incubated the disease for a fortnight. Although this difference could be accounted for by the difference in dose of virus inoculated, the presence of bacteria in the unfiltered inoculum may well have been a further factor in shortening the incubation period.

\section{Gastro-Intestinal Tract}

The inter-dependence of viruses and bacteria is not restricted to respiratory tract infections. It may flourish in the gastro-intestinal tract and possibly contributes to the production of such diseases as amoebic dysentery, infection hepatitis and poliomyelitis.

Amoebic dysentery remains essentially a tropical disease despite the apparently harmless occurrence of the entamoeba histolytica cyst in millions of persons in temperate climates. One of the theories advanced is that there may be a viral synergism which determines the invasiveness of the amoeba (Napier, 1947). There is no evidence to suggest the presence or absence of such a virus, and for this reason alone the possibility should not be ignored.

The association of the infective hepatitis virus and salmonellae has been noted by Havens and Wenner (1946) in experimentally-produced hepatitis in human volunteers. Two of the 23 volunteers contracting this viral disease also developed a salmonella bacteraemia. The frequency of the association is underlined by the fact that in the 'pre-virus' days of the first world war it was suggested that strains of paratyphoid bacilli were capable of acquiring an icterogenic capacity, so causing epidemic jaundice.

Recently it has been shown that a virus and a protozoon act synergistically in causing mouse hepatitis (Niven, Gledhill, Dick and Andrews, 1952). When inoculated alone neither virus nor protozoon seems capable of causing the disease, but when inoculated together fatal hepatitis is produced. The protozoon has been identified as the eperythrozoon coccoides. The mechanism of this mutual interdependence has not yet been elucidated.
The poliomyelitis virus probably has a gastrointestinal portal of entry. Little is known of the factors which influence its multiplication in the alimentary tract and subsequent penetration to the central nervous system. It is possible, although speculative, that concomitant bacterial invasion may lessen the local defensive resistance of the host, especially since it often coincides with attacks of gastro-enteritis and typhoid fever.

\section{Skin Diseases}

Synergistic action of the vaccinia virus and certain strains of staphylococci and streptococci has been demonstrated in the rabbit (Lack, 1948). Intracutaneous inoculations of mixtures of this virus and staphylococci cause a spread of the vaccinial lesion with an increased yield of virus. This is largely due to the hyaluronidase produced by certain cocci. Furthermore the reverse aspect of this symbiosis is also apparent. Staphylococci spread in proportion to their hyaluronidase production when injected with vaccinia virus, although they produce minimal lesions when injected alone.

This mechanism may, in part, explain the severity of secondary bacterial invasion in smallpox and spread with impetiginization of herpes labialis.

\section{Eye Diseases}

Trachoma is due to a virus, closely related to the psittacosis-lymphogranuloma group. Although no true symbiotic relationship exists between this virus and conjunctival bacteria, secondary bacterial infection increases the infectivity of trachoma. Transmission of the disease to other members of a family may only take place when an acute bacterial conjunctivitis occurs in a carrier of chronic trachoma (Thygeson, 195I).

Observations of great epidemiological interest are still within the province of the clinician although liaison with the virologist is essential for a more accurate understanding of virus diseases. By observation alone, the clinician has noted the frequent association of herpes simplex virus infection of the lip with a concomitant bacterial pneumonia, whereas it is rarely associated with a virus pneumonia. In a similar way the clinician is in a position to assess the effects of the new antibiotics in the control of bacterial and viral diseases and, in so doing, should, as far as possible, try to disentangle their bacteriostatic and virucidal properties.

\section{BIBLIOGRAPHY}

COMMISSION ON ACUTE RESPIRATORY DISEASES (1946), Fohns Hopkins Hosp. Bull., 79, 109.

DOCHEZ, A. R., MILLS, K. C., and KNEELAND, Y., JUN. (1932,) Proc. Soc. exp. Biol., N.Y., 30, 314. 
was involved, then the position might be analagous with some cases of thrombophlebitis in which we had seen a tendency of the broken 'vicious circle' to re-establish itself after a single block of the sympathetic (Steel I95I).

In retrospect it seems reasonable to assume that the sudden thrombosis of the calf vessels brought in its train a concomitant spasm of the femoral artery thus shutting off the collateral supply to the calf muscles, and producing claudication. Blocking of the sympathetic could do nothing to reopen the thrombosed vessel but successfully relaxed its proximal spastic section thereby releasing the collateral supply to the calf and abolishing the claudication

The literature on this subject shows that opinion is sharply divided on the validity of such a hypothesis and on the possible application of nerve block treatment

Pickering (I95I) states that vasospasm is a rare entity and is too readily invoked as a diagnosis. Homans (1943) speaks of arterial spasm caused by embolus as involving the arterial tree distal to the obstruction. Ochsner (I95I) however goes much further and says that acute arterial occlusion brings in its train reflex spasm in uninvolved vessels thus affecting the collateral supply. Leary and Allen (I94I) suggests that the residue of an acute thrombophlebitis might cause a ' reverse sensitivity' of the artery so that on exercise, it contracts instead of dilating. Pearl (1937) specifically speaks of the value of nerve block therapy in cases of claudication due to arteriospasm. Cohen (1944) states that neither deep anaesthesia nor spinal anaesthesia will relax major vessel spasm: but Homans (1933) concedes that a moderate degree of spasm of a great vessel assoc- iated with peripheral vasosbasm will probably b) relaxed by nerve blocking. More recently some cases of arterial spasm associated with intravenous infusion (Sutton, 1952: Vaughan, 1952) and with venepuncture (Redman, 1952) have been reported:-

The liability of a great vessel to go into spasm in response to injury in its neighbourhood is welf established. Is it then not possible that, wheres sudden occlusion of such a vessel takes place, the proximal part may react to this disaster within itso lumen in a similar manner? But even if this is so, then it still seems extraordinary that this state of balanced imbalance can be almost indefinitely $\overrightarrow{0}$ maintained and then be suddenly, and apparently permanently, reversed by but a temporary block $\sigma^{\circ}$ ing of the sympathetic pathways.

\section{Summary}

Treatment by nerve blocking of a case of inter mittent claudication complicating Polycythemia Vera has been described, together with the oscillometric changes brought about by thistreatment. The possible course of events hase been suggested.

I am grateful to Dr. Harold Davis for having referred the case to me and for permission top publish it.

BROWN, G. E, and GIPLIOGRAPHY

COHE, 705. (1944), Lancet, 1,1 .

HOMANS, J. (1943), Am. F. Med. Sci., 205, 313.

HORTON, B. T., and BROWN, G. E. (1929), Med. Clin. N. Ariet

LEARY, W. V., and ALLEN, E. V. (194I), Am. Heart F., 22, 艼 9

NORMÁN, I. L L, and ALLEN, E. V. (1937) Ibid., 13, 257.

OCHSNER, A. (1951), Curr. Res. Anaes., 30, 61 .

OPPENHEIMER, B.'S. (1929), Trans. Ass. Amer. Phys., 44, 338

PEARL, F. L. (1937), Am. Ұ. Med. Sci., 194, 505.

PICKERING, G. W.' (I95I), Lancet, ii, 845 .

RAY, E. S., and FORBES, G. E. (1948), Southern Med. F., 41, 1123 REDMAN,' T. F. (1952), Brit. med. F., ii, 1097.

STEEL, G. C. (1951), Anaesthesia, 6, 154 .

SUTTON, M. (1952), Brit. med.. ., ii, 859.

VAUGHAN, A. B. (1952), Ibid., ii, 1097.

\section{RUTHIN CASTLE, NORTH WALES}

A Clinic for the diagnosis and treatment of Internal Diseases (except Mental or Infectious Diseases). The Clinic is provided with a staff of doctors, technicians and nurses.

The surroundings are beautiful. The climate is mild. There is central heating throughout. The annual rainfall is 30.5 inches, that is, less than the average for England.

The fees are inclusive and vary according to the room occupied.

For particulars apply to THE SECRETARY, Ruthin Castle, North Wales.

Telegrams: Castle, Ruthin.

Telephone: Ruthin 66

Continuation of Bibliography-D. Geraint James, M.D.(Cantab.), M.R.C.P., from p. I9I

HAGAN, W. A., and BRUNER, D. W. (195I), 'The Infectious Diseases of Domestic Animals, with special reference to Etiology, Diagnosis and Biologic 'Therapy,' 2nd edition, London, Baillière, Tindall \& Cox.

HAVENS, W. P., JƯN., and WENNER, H. A. (1946), f. clin. Invest., 25, 45 .

LACK, C. H.' (1948), Brit. F. exp. Path., 29 , r9r.

MIRICK, G. S., THOMAS, L., CÚRNEN, E. C., and


NAPIER, L. E. (1947), F. trop. Med., 50, I69. NIVEN, J. S. F., GLEDHILL, A. W., DICK, G. W. A., and

SCADDING, J. G. (1937), Quart. F. Med., 30 (n.s. 6), 425.

THOPE, R. E. (1936), Medicine, 15, 453. . J. E., JUN., and HORSFALL, F. L., JUN. (1943), Science, D
$98,566$.

THYGESON, P. (I95I), Amer. 7. Ophthal., 34, 7. WOLLPER, O. C., and SCHWAB, J.'L. (I947), Ұ. exper. Med., 85, 199. 